\title{
Isolation, Identification, and Characterization of Cadmium Resistant Pseudomonas sp. M3 from Industrial Wastewater
}

\author{
Syed Zaghum Abbas, Mohd Rafatullah, Norli Ismail, and Japareng Lalung \\ Division of Environmental Technology, School of Industrial Technology, Universiti Sains Malaysia, 11800 Penang, Malaysia \\ Correspondence should be addressed to Mohd Rafatullah; mohd_rafatullah@yahoo.co.in
}

Received 23 January 2014; Revised 8 July 2014; Accepted 25 August 2014; Published 7 September 2014

Academic Editor: Alfieri Pollice

Copyright (C) 2014 Syed Zaghum Abbas et al. This is an open access article distributed under the Creative Commons Attribution License, which permits unrestricted use, distribution, and reproduction in any medium, provided the original work is properly cited.

\begin{abstract}
The present study deals with the isolation, identification, and characterization of the cadmium resistant bacteria from wastewater collected from industrial area of Penang, Malaysia. The isolate was selected based on high level of the cadmium and antibiotic resistances. On the basis of morphological, biochemical characteristics, $16 \mathrm{~S}$ rDNA gene sequencing and phylogeny analysis revealed that the strain RZCd1 was authentically identified as Pseudomonas sp. M3. The industrial isolate showed more than $70 \%$ of the cadmium removal in log phase. The cadmium removal capacity of strain RZCd1 was affected by temperature and $\mathrm{pH}$. At $\mathrm{pH} 7.0$ and $35^{\circ} \mathrm{C}$, strain RZCd1 showed maximum cadmium removal capacity. The minimal inhibitory concentration of strain RZCd1 against the cadmium was $550 \mu \mathrm{g} / \mathrm{mL}$. The resistance against the cadmium was associated with resistance to multiple antibiotics: amoxicillin, penicillin, cephalexin, erythromycin, and streptomycin. The strain RZCd1 also gave thick bands of proteins in front of $25 \mathrm{kDa}$ in cadmium stress condition after $3 \mathrm{~h}$ of incubation. So the identified cadmium resistant bacteria may be useful for the bioremediation of cadmium contaminated industrial wastewater.
\end{abstract}

\section{Introduction}

Among the list of heavy metals, the cadmium needs special attention because it is identified as significant pollutant due to its high solubility and toxicity in the water $[1,2]$. It is one of the most toxic pollutants of the surface soil layer, released into the environment by mining and smelting activities, atmospheric deposition from metallurgical industries, incineration of plastics and batteries, land application of sewage sludge, and burning of fossil fuels [3]. The wastewaters from the industries and sewage sludge applications have permanent toxic effects to human and the environment. Both terrestrial and aquatic environments have been greatly affected by the cadmium pollution [4]. In human, it affects cell proliferation, differentiation, apoptosis and increases oncogene activation to carcinogenesis. It also causes vertebral osteoporosis and fractures, toxicity to neuron, aging, and peripheral arterial disease. It selectively accumulates in pancreas, bones, renal liver, lungs, and kidneys $[5,6]$.
The water pollution caused by the cadmium has received increasing attention worldwide. Many conventional approaches have been considered for the removal of cadmium from industrial wastewater, mainly including chemical precipitation, ion exchange, membrane technology, and adsorption $[7,8]$. In the field of bioremediation, simpler and relatively inexpensive ways are more focusing than chemical treatment methods. Furthermore, many investigators have reported the bioaccumulation of cadmium onto natural microbial populations like bacteria and algae as the new bioremediation technology $[9,10]$. The microbes use various survival strategies to combat the cadmium stress that include metal ions sequestration, active efflux of metals; some use enzymatic detoxification and cadmium accumulation [11, 12].

In this work, a cadmium resistant strain RZCd1 was isolated from industrial wastewater and identified as Pseudomonas sp. M3 based on morphological observation, biochemical, physiological characterization, and partial 16S rDNA sequence analysis. The resistance against the cadmium 
and the antibiotic was examined. Furthermore, the removal capacity of the strain RZCd1 was also studied.

\section{Experimental}

2.1. Collection of Water Samples. The wastewater samples were collected from the industrial area of Penang, Malaysia, located in $5^{\circ} .07617^{\prime}, 5^{\circ} .38400^{\prime}, 5.41264^{\prime}$, and $5^{\circ} .329379^{\prime}$ " $\mathrm{N}$ " longitudes and $100^{\circ} .386119^{\prime}, 100^{\circ} .302104^{\prime}, 100^{\circ} .325307^{\prime}$, and $100^{\circ} .482284^{\prime}$ "E" latitudes. The industrial wastewater samples were collected in the screw capped bottles. The samples ranged in external $\mathrm{pH}$ from 6.0 to 7.0 , temperature varied from $29^{\circ} \mathrm{C}$ to $35^{\circ} \mathrm{C}$, and the cadmium range was $0.36 \pm$ $0.82 \mathrm{mg} / \mathrm{L}$.

2.2. Isolation of Cadmium Resistant Bacteria. The stock solutions of $10 \mu \mathrm{g} / \mathrm{mL}$ and $100 \mu \mathrm{g} / \mathrm{mL}$ of the cadmium were prepared by dissolving the cadmium chloride in the deionized water and sterilized by using $0.22 \mu \mathrm{m}$ pore-size sterile filters. The cadmium resistant bacteria were isolated by standard dilution method. The serially diluted water samples were sown on the nutrient agar plates which were loaded with $10 \mu \mathrm{g} / \mathrm{mL}$ of the cadmium solution. The bacterial strains which can tolerate the $10 \mu \mathrm{g} / \mathrm{mL}$ of the cadmium were isolated and further streaked on the agar plates with $100 \mu \mathrm{g} / \mathrm{mL}$ of the cadmium and then finally selected for further experiments.

2.3. Identification of Bacteria. After biochemical tests and staining, the isolated strain was preliminary identified according to the key of Bergey's Manual of Determinative Bacteriology [13]. Further bacterial isolate was characterized on the molecular base. First the bacterial genomic DNA was isolated by Triton-Prep method. The partial 16S rDNA was amplified by the PCR (polymerase chain reaction) with bacterial universal primers 27F ( $5^{\prime}$ AGAGTTTGATCMTGGCTCAG $3^{\prime}$ ) and 1492R ( $5^{\prime}$ TACGGYTACCTTGTTACGACTT $3^{\prime}$ ). The PCR was carried out with an initial denaturation step for $5 \mathrm{~min}$ at $94^{\circ} \mathrm{C}$, followed by 35 cycles of denaturation at $94^{\circ} \mathrm{C}, 30 \mathrm{sec}$ of annealing at $52^{\circ} \mathrm{C}$, and $40 \mathrm{sec}$ of elongation at $72^{\circ} \mathrm{C}$. The last step was a final extension at $72^{\circ} \mathrm{C}$ for $10 \mathrm{sec}$. The samples were experimented on the gels containing TBE buffer (EDTA $2 \mathrm{mM}$, Boric acid $89 \mathrm{mM}$, Tris $89 \mathrm{mM}$, and $\mathrm{pH}=7$ ) and the purification of the PCR products was done by Silica gel kit (Fermentas Co, Germany) and $25 \mu \mathrm{L}$ of the PCR products sent to Center of Chemical Biology, Universiti Sains Malaysia for sequencing. By using NCBI blast analysis, the $16 \mathrm{~S}$ rDNA sequences were submitted to the database of GenBank and compared with similar sequences. The phylogenetic tree of partial $16 \mathrm{~S}$ rDNA was constructed using the software Clustal W.

2.4. Minimum Inhibitory Concentration (MIC) against Cadmium. A stock solution of $1000 \mu \mathrm{g} / \mathrm{mL}$ of the cadmium was prepared. The M9 acetate minimal medium $(0.5 \mathrm{~g} / \mathrm{mL}$ yeast extract, $0.2 \mathrm{~g} / \mathrm{mL} \mathrm{MgSO}_{4}, 5.0 \mathrm{~g} / \mathrm{mL}$ sodium acetate, $0.001 \mathrm{~g} / \mathrm{mL} \mathrm{FeSO}_{4}, 0.001 \mathrm{~g} / \mathrm{mL} \mathrm{CaCl}_{2}, 0.5 \mathrm{~g} / \mathrm{mL} \mathrm{K}_{2} \mathrm{HPO}_{4}$, and $1.0 \mathrm{~g} / \mathrm{mL} \mathrm{NH}_{4} \mathrm{Cl}$ ) was used to check the MIC against the cadmium [14]. In each test tube $10 \mathrm{~mL}$ of the M9 acetate minimal medium was taken. After autoclaving, the medium was supplemented with $20 \mu \mathrm{L}$ overnight grown bacterial culture and consecutive addition of the cadmium ranged from 50 to $550 \mu \mathrm{g} / \mathrm{mL}$ and then finally incubated at $37^{\circ} \mathrm{C}$ for $24 \mathrm{~h}$. The growth was measured as optical density at $600 \mathrm{~nm}$.

2.5. Determination of Antibiotic Resistance. The antibiotic disks (Oxoid, Hampshire, England) contained 8 antibiotics: penicillin $(10 \mathrm{IU})$, tetracycline $(30 \mu \mathrm{g})$, amoxicillin $(10 \mu \mathrm{g})$, gentamycin $(10 \mu \mathrm{g})$, cephalexin $(30 \mu \mathrm{g})$, erythromycin $(15 \mu \mathrm{g})$, streptomycin $(10 \mu \mathrm{g})$, and ciprofloxacin $(5 \mu \mathrm{g})$. The strain was tested for its sensitivity to the 8 antibiotics. The $0.1 \mathrm{~mL}$ culture was spread on the LB agar plates. The antibiotic disks were placed on the plates and incubated at $37^{\circ} \mathrm{C}$ for 1-2 days.

2.6. Cadmium Removal Capacity. The isolated strain was grown in the Luria Bertani broth containing $100 \mu \mathrm{g} / \mathrm{mL}$ of the cadmium. During the growth period, $1 \mathrm{~mL}$ of bacterial culture sample was removed into eppendorf tube after every four hour until $24 \mathrm{~h}$ and centrifuged at $6000 \mathrm{rpm}$ (revolutions per min). To check the effect of temperature and $\mathrm{pH}$, the isolated strain was grown at different temperatures $\left(5-45^{\circ} \mathrm{C}\right)$ and different $\mathrm{pH}$ (1.0-13.0). An extra sample without the addition of bacterial culture was prepared as control. The supernatants were collected and stored at $4^{\circ} \mathrm{C}$ for the cadmium analysis. The cadmium concentrations in the supernatants were analyzed with a GBC932 atomic absorption spectrometry (Pantech Instruments, Blackburn, Victoria, Australia) at $228.8 \mathrm{~nm}$ with a cadmium hollow cathode lamp. The optimal density of each sample was also measured at $600 \mathrm{~nm}$ to compare the growth rate of bacteria with the cadmium removal capacity [6].

2.7. Protein Profiling. In the conical flasks, $20 \mathrm{~mL}$ of the Luria Bertani broth was taken in triplicate and steam sterilized. The bacterial isolate was stressed with concentration of the cadmium $350 \mu \mathrm{g} / \mathrm{mL}$ and with control. Then these conical flasks were incubated for $3 \mathrm{~h}$ at $37^{\circ} \mathrm{C}$ in shaking incubator and harvest the cells by centrifugation. The pellet was dissolved in $100 \mu \mathrm{L}$ of the $1 \mathrm{x}$ loading dye then heat shock was given for $5 \mathrm{~min}$; eppendorf tube was shifted on ice for $2 \mathrm{~min}$ and then was centrifuged at $12000 \mathrm{rpm}$ for $10 \mathrm{~min}$. The supernatant was transferred to a new eppendorf tube, then final centrifugation was done at $12000 \mathrm{rpm}$ for $10 \mathrm{~min}$ and the supernatant was shifted to a new eppendorf tube. Initially gel was run at $40 \mathrm{mV}$ after stake formation and the voltage was increased to $80 \mathrm{mV}$.

\section{Results and Discussion}

3.1. Bacterium Isolation. There were a few small colonies on the agar plate with $10 \mu \mathrm{g} / \mathrm{mL}$ of the cadmium after incubating for 2-3 days. When the cadmium concentration increased up to $100 \mu \mathrm{g} / \mathrm{mL}$ and incubated for 3 days, only single colony was able to grow on the plate. The colony was streaked on the agar plate to get the purified bacterium and denoted as strain RZCd1. 
TABLE 1: Characteristics of the strain RZCd1.

\begin{tabular}{lc}
\hline Characteristics & Strain RZCd1 \\
\hline Morphological observation & Off-white \\
Colony color & Gram-negative \\
Gram nature & Coccus \\
Cell shape & Round \\
Colony shape & Positive \\
Motility & Negative \\
Spore formation & \\
Biochemical tests & Positive \\
Catalase test & Negative \\
Urease test & Positive \\
Gelatin hydrolysis test & Negative \\
Carbohydrate test & Negative \\
MRVP test & Positive \\
Citrate test & Positive \\
Blood agar test & Positive \\
Chocolate agar test & \\
Antibiotics sensitivity profiles & Retracycline $(30 \mu \mathrm{g})$ \\
Amoxicillin $(10 \mu \mathrm{g})$ & 23 mm (sensitive) \\
Penicillin $(10$ units) & Resistant \\
Gentamycin $(10 \mu \mathrm{g})$ & Resistant \\
Cephalexin $(30 \mu \mathrm{g})$ & Resistant \\
Erythromycin $(15 \mu \mathrm{g})$ & Resistant \\
Streptomycin $(10 \mu \mathrm{g})$ & mm (sensitive) \\
Ciprofloxacin $(5 \mu \mathrm{g})$ & \\
\hline
\end{tabular}

3.2. Identification of Bacterial Strain. The colony of strain RZCd1 was round and off-white in color. The bacterium was Gram-negative and had polar flagellum, without capsule and spore. The Gram staining observation showed that it was coccus in shape. The morphological and biochemical characteristics of strain RZCd1 are listed in Table 1. According to Manual of Determinative Bacteriology, comparing strain RZCd1 with other bacteria, the strain was similar to Pseudomonas sp. The partial 16S rDNA gene sequence of the strain RZCd1 was amplified by PCR. The partial $16 S$ rDNA sequence of strain RZCd1 was submitted to the database of GenBank and the accession number was KF146957. The BLAST analysis showed that the partial 16S rDNA of strain RZCd1 had more than $95 \%$ similarity index with that of Pseudomonas sp. M3. In order to determine the relationship between strain RZCd1 and the other Pseudomonas species, the phylogenetic tree based on partial $16 \mathrm{~S}$ rDNA was constructed as shown in Figure 1. So based on the results of physiological, morphological, biochemical characteristics and 16S rDNA sequence analysis, strain RZCd1 was identified as Pseudomonas sp. M3.

3.3. Resistance against Cadmium. The tolerance test indicated that maximum cadmium tolerance was up to $550 \mu \mathrm{g} / \mathrm{mL}$ as shown in Figure 2. The optical density was decreased with the increase of the cadmium concentration which indicated the toxic effect of cadmium on the growth of bacterium. The bacterium was exposed to the cadmium for a long time, which might change its structure and function to adapt to the cadmium-polluted environment, such as smaller size of bacteria, acquisition of resistance factors, and gene mutation. The high levels of resistance to the cadmium and antibiotics might be associated with its complex survival environment [15]. The strain RZCdl can grow in the cadmium solution with the high level of resistance. So it is possible to remove the cadmium from wastewater containing cadmium.

3.4. Antibiotic Profile. The susceptibility test of strain RZCd1 against different antibiotics is showed in Table 1. This strain showed only sensitivity against tetracycline, gentamycin, and ciprofloxacin while it was resistant against amoxicillin, penicillin, cephalexin, erythromycin, and streptomycin. The ability of the microorganisms to resist against antibiotics and cadmium seems to be the result of exposure to cadmium contaminated environments that cause coincidental selection of resistance factors for antibiotics and cadmium [16].

3.5. Cadmium Uptake Capacity. The cadmium removal capacity of strain RZCd1 was shown in Figure 3. The lag phase was observed during the initial $0-4 \mathrm{~h}$ which was another sign of the cadmium toxicity to strain RZCd1. In this lag phase strain RZCd1 removed only $5.34 \%$ of the cadmium. In fact when a microorganism is inoculated into a new culture containing toxic substances, the cells will damage due to pollutant toxicity. In this situation the microorganism expands energy to repair cell damage and adapt its enzymatic pathway to a new condition [17]. After that in log phase (8-16 h), strain RZCd1 removed the maximum amount of the cadmium which is about $74.21 \%$ because in this phase bacteria rapidly divide with time so bioaccumulation of the cadmium also increased. The percentage of the cadmium bioaccumulation by strain RZCd1 was increasing from the beginning until $16 \mathrm{~h}$. After $16 \mathrm{~h}$, a slight reduction in cadmium removal was observed in the medium. Some investigators believed that when metal bioaccumulation reaches its maximum level, growth would be decrease and the number of viable cells in the culture would be reduced [11]. If so, it is suggested that glycoprotein materials components in the cell wall of dead bacteria might be degraded by viable cells. This condition leads to the release of the absorbed metals into the aqueous solution.

The capacity of strain RZCd1 to remove cadmium ions from aqueous solutions was also significantly influenced by environmental growth conditions, as $\mathrm{pH}$ and temperature as shown in Figures 4 and 5. Studying the effect of different temperatures revealed that $35^{\circ} \mathrm{C}$ was the optimum temperature for the cadmium uptake by strain RZCd1, because temperature effects are confined to metabolism-dependent metal accumulation [18]. These results were in agreement with Zeng et al. [6] who mentioned that maximum cadmium removal by Pseudomonas aeruginosa strain E1 was at $36^{\circ} \mathrm{C}$. The removal of the cadmium from nutrient broth media was also influenced by $\mathrm{pH}$ values. In the present study maximum cadmium uptake capacity was obtained at $\mathrm{pH}$ 7.0, while $\mathrm{pH} 1.0$ and 13.0 were suppressive values for strain RZCd1. The $\mathrm{pH}$ of the solution plays a major role in the extent 


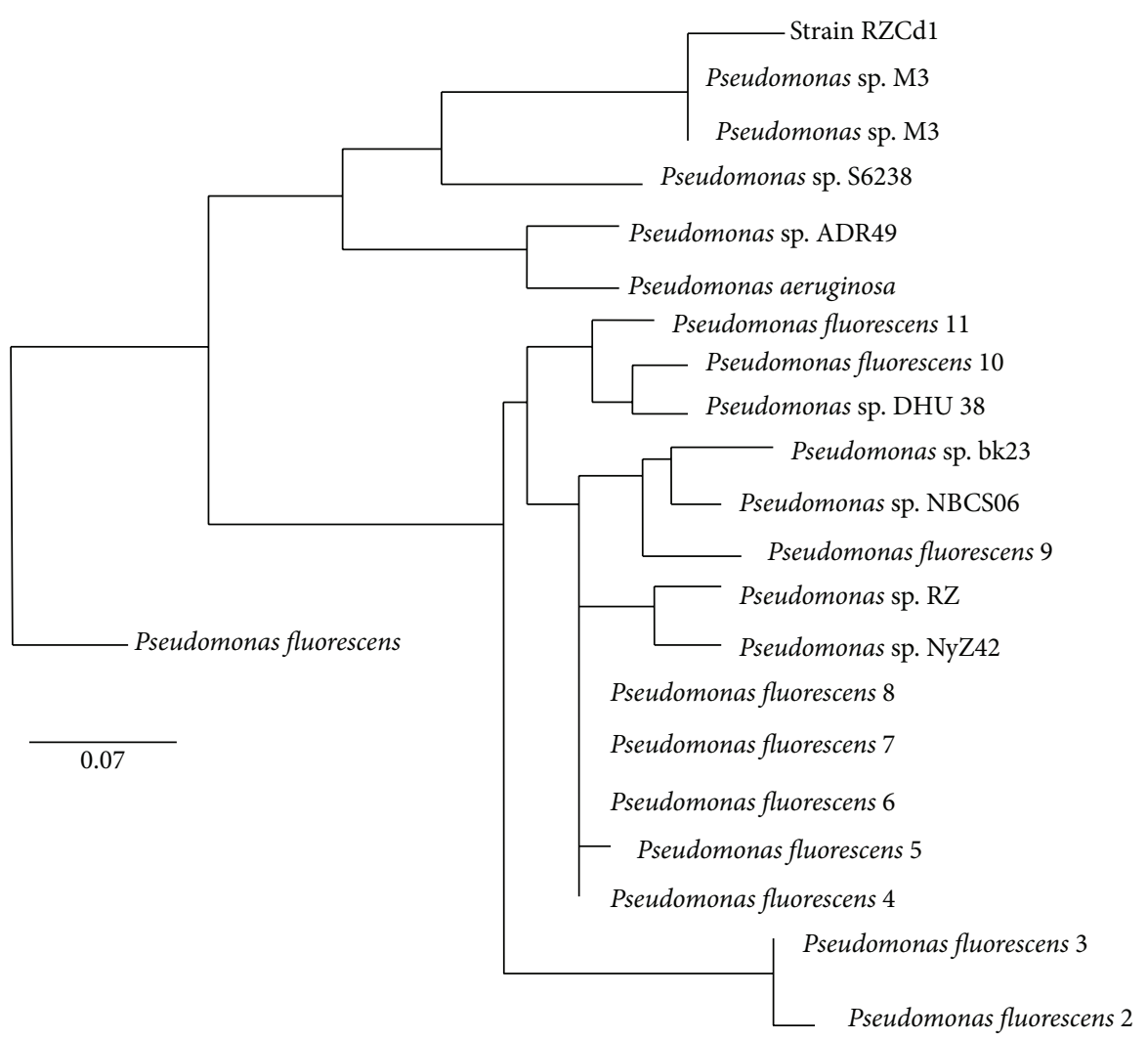

FIGURE 1: Phylogenetic development trees based on 16S rDNA analysis of strain RZCd1 (Pseudomonas sp. M3) while scale bar corresponds to nucleotide sequence difference.

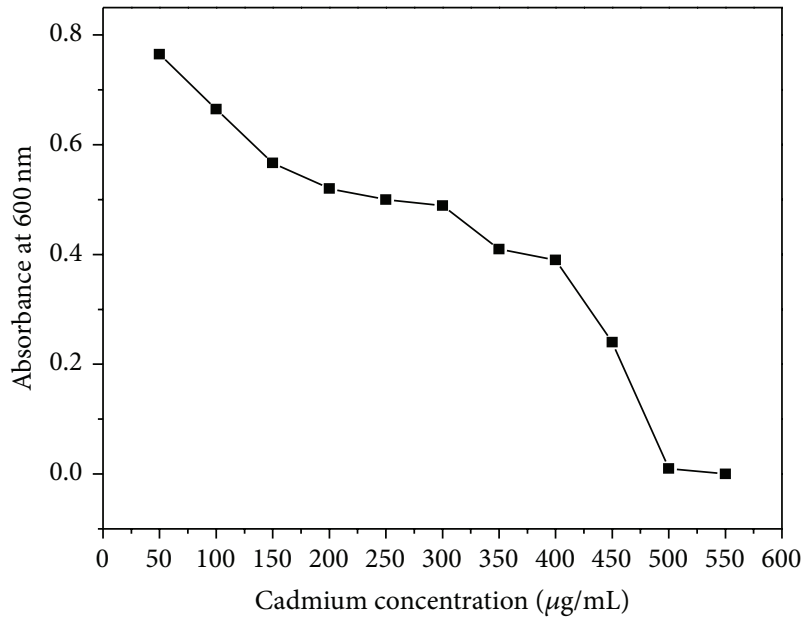

FIGURE 2: The minimum inhibitory concentration of the strain RZCd1 against cadmium.

of metals binding to microorganisms [19]. The variations in external $\mathrm{pH}$ can also affect the degree of protonation of potential ligand that contributes to metal binding [20]. The Pseudomonas fluorescens also showed maximum cadmium removal at $\mathrm{pH} 6.8$ [21].

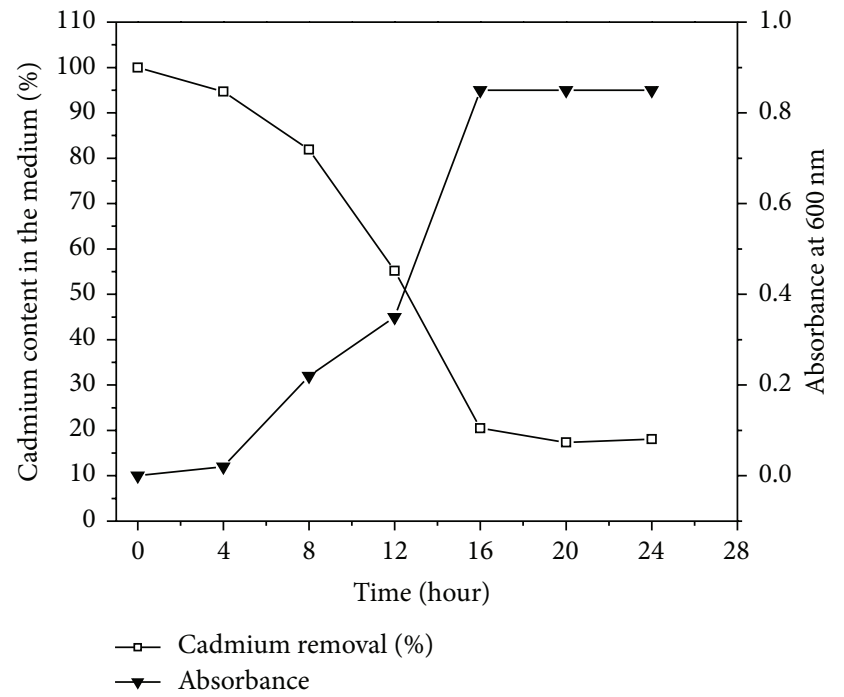

FIGURE 3: Removal of cadmium after inoculation of the bacterial strain RZCd1.

3.6. Protein Bands. The proteins bands of strain RZCd1 in stressed and non-stressed medium were shown in Figure 6. The $3 \mathrm{~h}$ stressed culture gave thick protein bands of strain RZCd1 in front of $25 \mathrm{kDa}$. These results were standing with 


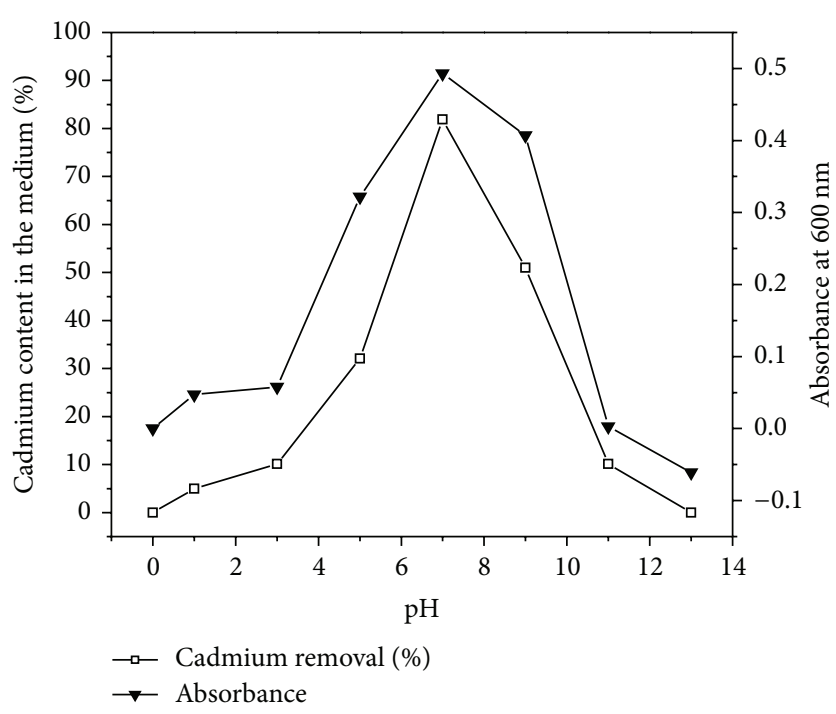

FIgURE 4: The effect of different $\mathrm{pH}$ on the removal of cadmium ions by the strain RZCdl.

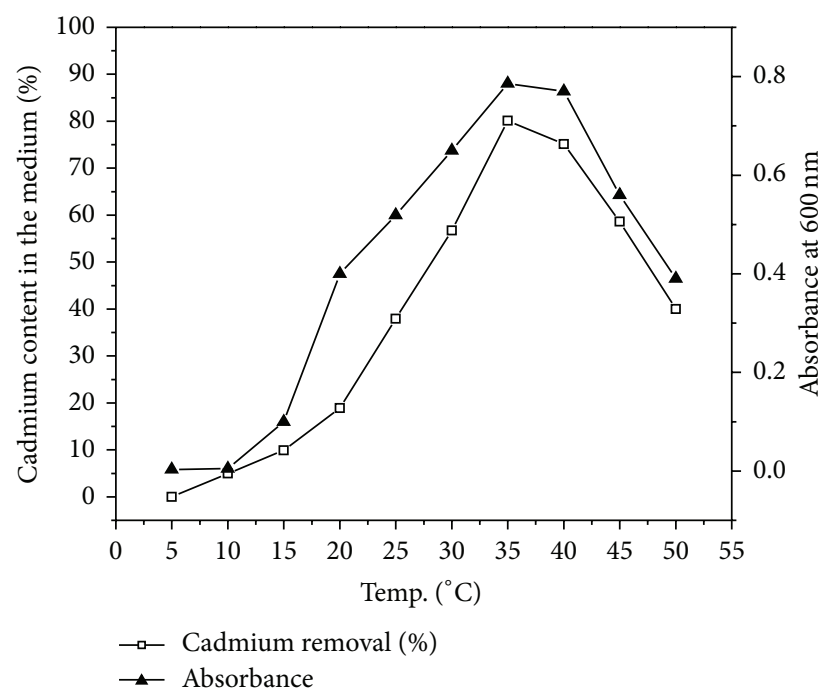

FIGURE 5: The effect of different temperatures on the removal of cadmium ions by the strain RZCd1.

metaproteomic analysis of a bacterial community response to the cadmium-stressed and nonstressed bands of proteins obtained in front of $25 \mathrm{kDa}$ [22]. So, more than 100 unique differentially expressed proteins were identified through database searching and de novo sequencing. The proteins of importance in the cadmium shock included ATPases, oxidoreductases, and transport proteins. The ability of proteomics to detect the differential regulation of these proteins even during short cadmium exposures shows that it is a powerful tool in explaining cellular mechanisms for a mixed culture [23].

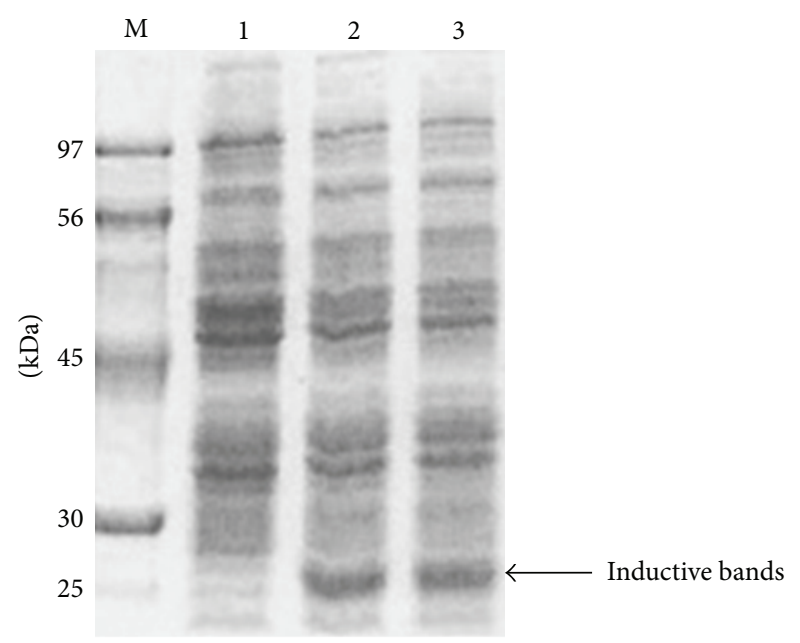

FIGURE 6: $\mathrm{M}$ indicating the marker 1 representing nonstress protein bands of the strain RZCd1 while 2 and 3 lines indicating protein bands of the strain RZCd1 in cadmium stress condition.

\section{Conclusions}

Due to continued unsustainable levels of human and natural exploitation, search for alternative techniques for treatment of the cadmium contaminated wastewater came into existence. The cadmium bioremediation approach has attracted much attention because it is environment friendly, safe, and economical. We concluded that the Gram-negative strain RZCd1 has resistance against cadmium up to $550 \mu \mathrm{g} / \mathrm{mL}$ and antibiotics. The ability of the strain RZCd1 to tolerate antibiotics and cadmium appears to be the result of exposure to cadmium contaminated environments that cause coincidental selection of resistance factors for cadmium and antibiotics. The elucidation of the exact resistance mechanisms needs further investigation.

\section{Conflict of Interests}

The authors declare that they do not have any conflict of interests.

\section{Acknowledgment}

The authors acknowledge the research grant provided by the Universiti Sains Malaysia under the Short Term Grant Scheme (Project no. 304/PTEKIND/6312118).

\section{References}

[1] U. C. Gupta and S. C. Gupta, "Trace element toxicity relationships to crop production and live stock and human health: implications for management," Communications in Soil Science and Plant Analysis, vol. 29, no. 1, pp. 1491-1522, 1998.

[2] X.-Y. Tang, Y.-G. Zhu, Y.-S. Cui, J. Duan, and L. Tang, “The effect of ageing on the bioaccessibility and fractionation of cadmium in some typical soils of China," Environment International, vol. 32, no. 5, pp. 682-689, 2006. 
[3] M. Filipič, T. Fatur, and M. Vudrag, "Molecular mechanisms of cadmium induced mutagenicity," Human and Experimental Toxicology, vol. 25, no. 2, pp. 67-77, 2006.

[4] X. Deng, X. E. Yi, and G. Liu, "Cadmium removal from aqueous solution by gene-modified Escherichia coli JM109," Journal of Hazardous Materials, vol. 139, no. 2, pp. 340-344, 2007.

[5] M. P. Benavides, S. M. Gallego, and M. L. Tomaro, "Cadmium toxicity in plants," Brazilian Journal of Plant Physiology, vol. 17, no. 1, pp. 21-34, 2005.

[6] X. X. Zeng, J. X. Tang, X. D. Liu, and P. Jiang, "Isolation, identification and characterization of cadmium-resistant-Pseudomonas aeruginosa strain E1," Journal of Central South University of Technology, vol. 16, no. 3, pp. 416-421, 2009.

[7] A. Ahmad, M. Rafatullah, and M. Danish, "Sorption studies of $\mathrm{Zn}(\mathrm{II})$ - and $\mathrm{Cd}(\mathrm{II})$ ions from aqueous solution on treated sawdust of sissoo wood," Holz als Roh, vol. 65, no. 6, pp. 429436, 2007.

[8] T. Ahmad, M. Rafatullah, A. Ghazali, O. Sulaiman, and R. Hashim, "Oil palm biomass-based adsorbents for the removal of water pollutantsa review," Journal of Environmental Science and Health C: Environmental Carcinogenesis and Ecotoxicology Reviews, vol. 29, no. 3, pp. 177-222, 2011.

[9] M. Rafatullah, O. Sulaiman, R. Hashim, and A. Ahmad, "Removal of cadmium (II) from aqueous solutions by adsorption using meranti wood," Wood Science and Technology, vol. 46, no. 1-3, pp. 221-241, 2012.

[10] M. Pérez-Rama, E. Torres, C. Suárez, C. Herrero, and J. Abalde, "Sorption isotherm studies of $\mathrm{Cd}(\mathrm{II})$ ions using living cells of the marine microalga Tetraselmis suecica (Kylin) Butch," Journal of Environmental Management, vol. 91, no. 10, pp. 2045-2050, 2010.

[11] S. Sinha and S. K. Mukherjee, "Pseudomonas aeruginosa KUCd1, a possible candidate for cadmium bioremediation," Brazilian Journal of Microbiology, vol. 40, no. 3, pp. 655-662, 2009.

[12] S. Panwichian, D. Kantachote, B. Wittayaweerasak, and M. Mallavarapu, "Removal of heavy metals by exopolymeric substances produced by resistant purple nonsulfur bacteria isolated from contaminated shrimp ponds," Electronic Journal of Biotechnology, vol. 14, no. 4, p. 2, 2011.

[13] G. Holt, R. Krieg, H. Sneath, T. Staley, and T. Williams, Bergey's Manual of Determinative Bacteriology, Williams and Wilkins, Baltimore, Md, USA, 1994.

[14] A. R. Shakoori, M. Makhdoom, and R. U. Haq, "Hexavalent chromium reduction by a dichromate-resistant gram-positive bacterium isolated from effluents of tanneries," Applied Microbiology and Biotechnology, vol. 53, no. 3, pp. 348-351, 2000.

[15] R. Varghese, "Bioaccumulation of cadmium by pseudomonas Sp. Isolated from metal polluted industrial region," Environmental Research, Engineering and Management, vol. 61, no. 3, pp. 58-64, 2012.

[16] P. Kidd, J. Barceló, M. P. Bernal et al., "Trace element behaviour at the root-soil interface: implications in phytoremediation," Environmental and Experimental Botany, vol. 67, no. 1, pp. 243259, 2009.

[17] P. Gikas, S. Sengör, T. Ginn, J. Moberly, and B. Peyton, "The effects of heavy metals and temperature on microbial growth and lag," Global Nest Journal, vol. 11, no. 3, pp. 325-332, 2009.

[18] A. Öztürk, "Removal of nickel from aqueous solution by the bacterium Bacillus thuringiensis," Journal of Hazardous Materials, vol. 147, no. 1-2, pp. 518-523, 2007.
[19] G. Haferburg and E. Kothe, "Microbes and metals: interactions in the environment," Journal of Basic Microbiology, vol. 47, no. 6, pp. 453-467, 2007.

[20] T. O’Mahony, E. Guibal, and J. M. Tobin, "Reactive dye biosorption by Rhizopus arrhizus biomass," Enzyme and Microbial Technology, vol. 31, no. 4, pp. 456-463, 2002.

[21] C. Sarin and S. Sarin, "Removal of cadmium and zinc from soil using immobilized cell of biosurfactant producing bacteria," EnvironmentAsia, vol. 3, no. 2, pp. 49-53, 2010.

[22] C. M. R. Lacerda, L. H. Choe, and K. F. Reardon, "Metaproteomic analysis of a bacterial community response to cadmium exposure," Journal of Proteome Research, vol. 6, no. 3, pp. 11451152, 2007.

[23] K. J. Waldron and N. J. Robinson, "How do bacterial cells ensure that metalloproteins get the correct metal?" Nature Reviews Microbiology, vol. 7, no. 1, pp. 25-35, 2009. 

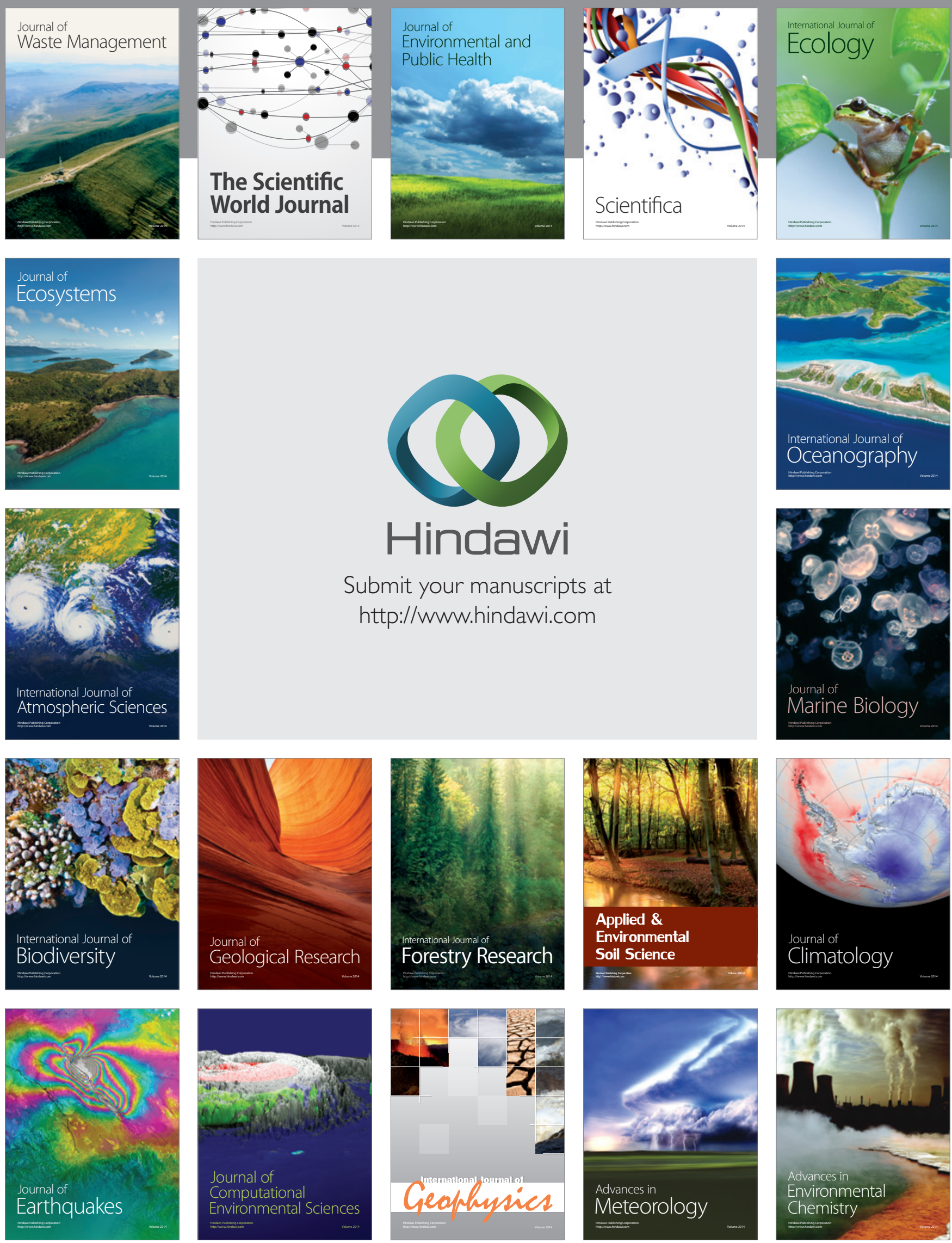